\title{
100 Percent of the Time
}

National Cancer Institute

\section{Source}

National Cancer Institute. 100 Percent of the Time. NCI Thesaurus. Code C157469.

An indication that an individual did something, or something occurred, 100 percent of the time. 